\title{
Biologically Inspired Design: Methods and Validation
}

\author{
Carlos A. M. Versos and Denis A. Coelho \\ Universidade da Beira Interior \\ Portugal
}

\section{Introduction}

Design inspired by nature, bionic design, biomimetism, biomimicry, or biologically inspired design, despite having been a source of inspiration for design activities for a long time, have recently, under pressure from sustainability concerns, gained a role as part of a standard set of approaches to deal with design problems. Nature provides an important model to find solutions to the ecological crisis. The aim of this chapter is to establish a comparison among a set of design methods, meant to guide industrial designers in carrying out activities leading to bio-inspired design. The results of literature review are presented, with emphasis drawn on existing documented approaches to design inspired by nature, and the presentation of the methods, on which a comparative analysis is established. The parameters for the comparative analysis are set out, based on five general goals that are considered applicable to design problems, within the realm of industrial design. The presentation and explanation of the comparisons is followed by a discussion on their implications for theory and practice.

The present day's urgency in achieving environmental sustainability has promoted renewed interest on gathering inspiration from nature in order to create novel design concepts. Design endeavours in several technical disciplines may lead to ground-breaking new concepts when natural systems are considered as a source of inspiration. The focus of this chapter is on joining a bio-inspired approach to the creation of industrial design engineering concepts with a systematic approach to design. The conduction of industrial design engineering projects is inherently structured and supported by methods set forth in the systematic design literature (e.g. Hales 1991, Hubka \& Eder 1992, Roozenburg \& Eekels 1995, Pahl \& Beitz 1996, Ulrich \& Eppinger 2004). Hence, in order to be useful and of practical value to the generation of industrial design engineering concepts, bio-inspired design methods should be able to fit into design endeavours that follow a systematic approach to design.

The main purpose of bionics is to carry out a benchmark of nature, of what it created, tested and has evolved over millions of years, in order to improve what man creates artificially (Benyus 1997). A number of design methods, intended especially to guide industrial designers in carrying out the development of biologically inspired design, have been proposed. The chapter establishes a comparative analysis between five methods, retrieved from literature. The methods are presented in similar depth, and the parameters of analysis 
are also described. The five bio-inspired design methods discussed, following an analytical direction that involves seeking inspiration in nature to solve a given problem, were retrieved from literature and are summarily presented. These methods are analysed in this chapter with regard to their perceived capacity to support the satisfaction of the five chosen high level design aims. These aims were selected considering their high degree of perceived relevance to industrial design engineering problems. A critique of the bio-inspired design methods retrieved is laid out, informed by comparison between the methods regarding their ability to support the satisfaction of the goals. The analysis is based on the scrutiny of the five methods, in relation to the support given towards the satisfaction of five goals, considered of paramount importance, and which are present in typical design projects, albeit translated into a number of requirements, specific to the problem at hand. The comparative analysis is intended to support designers in the process of selecting a design method that is adequate to the problem at hand. The analysis also identifies goals where the methods considered offer no or reduced support for their satisfaction, hence identifying the need for novel methodological proposals. The need to integrate validation activities in the bio-inspired design processes is also emphasized as a result of the analysis and followed through by the proposal of explicit procedures for validation of the satisfaction of goals sought by those pursuing biologically inspired design. This approach is intended to enable the evaluation of outcomes attained with the use of bio-inspired design methods, offering methodological support to designers in order to pursue the validation of bio-inspired concepts generated by them. These validation procedures are demonstrated in a specific design case with the purpose of exemplifying the application of the validation steps proposed. The requirements initially considered for the development of the product functionality considered in the case are also presented and a solution that is proposed to fulfil these requirements, generated using a bio-inspired approach, is evaluated, according to the validation approach presented.

The deployment of the validation process proposed is done within an iterative design case, consisting of a novel CD rack, which draws inspiration form nature, as its main solution principle is inspired on the spider-web. The process of validation makes use of surveys, conceptual-analytical arguments and standard engineering design procedures.

\section{Bio-inspired design}

The term bionic system, or bio-inspired systems, generally has two usual interpretations, concerning different application domains. The popular interpretation, based frequently on science fiction, is associated to more or less fantastic super-powers, to cybernetics and to robotic creations or additions to organisms. In this line of thought, bionics is presented as a science uniting biology and mechanics, producing devices that capacitate human beings with enhanced powers, whether to compensate for innate or acquired physical limitations, or for mere enhancement. Besides this interpretation, the term bionics is associated with the original meaning of biomimetism (bios - life, mimesis - imitation). According to Benyus (1997), biomimetism is a way to see and value nature, representing a novel mindset based not on what can be extracted from the natural world, but what can be learnt from it. This interpretation is the one of concern in this contribution. In this view, the main purpose of bionics is to carry out a benchmark of nature, of what it created, tested and has evolved over millions of years, in order to improve what man creates artificially. 
In the following sub-sections, the origins and evolution of bionics are summarily reviewed, while recalling a few well known examples of bio-inspired design solutions. Arguing for the growing importance of design inspired by nature for industrial designers, the section ends with the presentation of five bio-inspired design methods that will come under scrutiny in the remaining sections of the chapter.

\subsection{Origins and evolution of bio-inspired design}

Although the terminology of this area of design is relatively recent - appearing for the first time in the U.S.A. in 1958, by the hand of Jack E. Steele (Lloyd, 2008) - the practice, creation and inspiration through learning about nature comes from the most remote and pre-historic times. Primitive human beings used bone harpoons, which were serrated on their edges, to improve their piercing ability. This feature was likely inspired by animal teeth.

Leonardo da Vinci was probably the first systematic student of the possibilities of bionics (Lage and Dias, 2003). From the classical times of the Icarus legend, to the drawings of Leonardo da Vinci, man's dream to fly originated in the observation of bird and insect flight. Leonardo da Vinci realized that the human arms were too weak to flap wings for a long time, and hence developed several sketches of machines he called ornitopters (Kindersley, 1995). Human flight would only be possible in the XXth century, with the aid of the internal combustion engine and the propeller, but the inspiration from nature is anyway at its onset. One of the most disseminated examples of bio-inspired design is Velcro, invented in 1948, by Swiss engineer George de Mestral, from inspiration he got while observing thistles and the way they got caught in his dog's tail and adhered to clothes. In current times, designers Luigi Colani and Ross Lovegrove have been instrumental in portraying the use of bionics in their creations. Colani became notorious by the use of biodynamic forms in products such as automobiles and airplanes, during the second half of the XXth century (Pernodet and Mehly, 2000). Lovegrove's designs typically demonstrate a link between organic shapes and material science (Lovegrove, 2004). While a bio-inspired approach to design may not represent a universal tool that is applicable to any problem, it may provide support to design activities (Colombo, 2007). A set of five bio-inspired approaches to design, documented in literature, are presented in the following sub-section.

\subsection{Methods for bio-inspired design}

The goal of bio-inspired design methods consists in offering designers an organized process in order to attain a model that may be applied in design, inspired by the relations between form and function in nature (Colombo, 2007). Despite the success attained in several cases from the use of this approach in design, the bio-inspired design approach may still have room for improvement, in order to become more systematic. Five existing methods have been collected from literature and are presented in Tables 1 to 5 .

The design method presented in Table 1 emphasizes the importance of environmental and economical sustainability factors in the development and evaluation of the project by the designer. This method shows little support for organization problems. The method presented in Table 2 provides a detailed description of the procedures involved in natural sample collection and analysis. It also prescribes completely listing the working principles of the natural system. However, this method does not include any procedures concerning the design transfer of the features found in the natural samples. The design method presented in Table 3 gives emphasis to the product life cycle, by giving consideration to issues such as 
manufacturing processes, packaging and recycling of the product in development. In this method, iterations are implicit, and evaluation of the result of every step is also recommended.

\begin{tabular}{|c|c|}
\hline Phase & Description \\
\hline 1. Analysis & $\begin{array}{r}\text { Choice and analysis of a natural system. } \\
\text { The purpose of this phase is to understand the form, structure and } \\
\text { functional principles of the natural system. }\end{array}$ \\
\hline 2. Transformation & $\begin{array}{r}\text { Extrapolation of mathematical, geometrical and statistical principles } \\
\text { through a process of abstraction and simplification. } \\
\text { Transformation, by the analysis of the analogy, of the characteristics of } \\
\text { the biological system into technical and mechanical terms. }\end{array}$ \\
\hline 3. Implementation & $\begin{array}{c}\text { Implement the principles of the relationship between form and } \\
\text { structure found in the natural system analysis, for the development of } \\
\text { new products. }\end{array}$ \\
\hline 4. Product \\
development & $\begin{array}{c}\text { Development and evaluation of a new product taking the } \\
\text { environmental and economic factors for all life stages of the product } \\
\text { into account. }\end{array}$ \\
\hline
\end{tabular}

Table 1. The Aalborg bio-inspired design method (Colombo, 2007).

\begin{tabular}{|c|c|c|}
\hline Phase & $\begin{array}{c}\text { Description } \\
\text { 1. Identification of } \\
\text { need }\end{array}$ & $\begin{array}{c}\text { Identification of an unmet need in a satisfactory manner and that } \\
\text { allows the satisfaction of a particular problem and accurately, for } \\
\text { subsequent analysis of the environment in search of potential } \\
\text { solutions. }\end{array}$ \\
\hline $\begin{array}{c}\text { 2. Selection and } \\
\text { sampling }\end{array}$ & $\begin{array}{c}\text { Practical process step involving the selection of samples in nature that } \\
\text { fit the problem and the need at hand. Involves the search for samples } \\
\text { in nature and some knowledge about the habitat of the samples to be } \\
\text { collected and of the equipment to be used for the collection. }\end{array}$ \\
\hline $\begin{array}{c}\text { 3. Observation of } \\
\text { the sample }\end{array}$ & $\begin{array}{c}\text { Observation and analysis of the components of the morphological } \\
\text { structure, functions and processes, of the distributions in time and } \\
\text { space and of the relationship with the environment. Classification of } \\
\text { the sample. }\end{array}$ \\
\hline $\begin{array}{c}\text { 4. Analogy of the } \\
\text { natural system } \\
\text { with the product }\end{array}$ & $\begin{array}{c}\text { Through the information of functional analysis, morphology and } \\
\text { structure, the designer has the capacity to start considering the } \\
\text { possibility and feasibility of application of an analogy between the } \\
\text { sample studied and the product to design. }\end{array}$ \\
\hline $\begin{array}{c}\text { 5. Design } \\
\text { implementation }\end{array}$ & $\begin{array}{c}\text { Considering the feasibility of application of the sample } \\
\text { characteristics to the design and from the functional, formal and } \\
\text { structural analysis, as well as the needs and requirements of the } \\
\text { proposed product, an analysis of the system is held at this } \\
\text { stage. }\end{array}$ \\
\hline
\end{tabular}

Table 2. The biomimicry design method (Junior et al., 2002). 


\begin{tabular}{|c|c|}
\hline Phase & Description \\
\hline 1. Identify & $\begin{array}{l}\text { Development of the Design Brief for a human need with the details and } \\
\text { specifications of the problem to be solved. }\end{array}$ \\
\hline 2. Interpret & $\begin{array}{l}\text { Biological view of the problem. Questioning the Design Brief from the } \\
\text { perspective of nature. Translation of the functions of the project into } \\
\text { tasks performed in nature. }\end{array}$ \\
\hline 3. Discover & $\begin{array}{l}\text { Find the best natural models to answer / address the challenges } \\
\text { posed. }\end{array}$ \\
\hline 4. Abstract & $\begin{array}{l}\text { Select the "champions" with the strategies most relevant to a particular } \\
\text { challenge of the project. }\end{array}$ \\
\hline 5. Emulate & $\begin{array}{l}\text { Developing ideas and solutions based on natural models to mimic } \\
\text { aspects of form, function and of the ecosystem as much as possible. }\end{array}$ \\
\hline 6. Evaluate & $\begin{array}{c}\text { Evaluate the design solution considering the principles of life. Identify } \\
\text { ways to improve the design and bring forward questions to explore } \\
\text { issues such as those related to packaging, marketing, transportation, } \\
\text { new products, additions and refinements. }\end{array}$ \\
\hline 7. Identify & $\begin{array}{l}\text { Develop and refine design briefs based on lessons learned from } \\
\text { evaluation of life's principles. }\end{array}$ \\
\hline
\end{tabular}

Table 3. The spiral design method (Biomimicry Institute, 2007).

\begin{tabular}{|c|c|}
\hline Phase & Description \\
\hline $\begin{array}{l}\text { 1. Problem } \\
\text { definition }\end{array}$ & $\begin{array}{l}\text { Selection of a problem to solve and performing further definition of it } \\
\text { through functional decomposition and optimization. }\end{array}$ \\
\hline $\begin{array}{l}\text { 2. Reframe the } \\
\text { problem }\end{array}$ & $\begin{array}{c}\text { Redefining the problem using broadly applicable biological terms. } \\
\text { Asking the question: "How do biological solutions perform this } \\
\text { function?" }\end{array}$ \\
\hline $\begin{array}{l}\text { 3.Biological } \\
\text { solution search }\end{array}$ & $\begin{array}{c}\text { Find solutions that are relevant to the biological problem with } \\
\text { techniques such as changing constraints, analysis of natural champions } \\
\text { of adaptation, variation within a family of solutions and multi- } \\
\text { functionality. }\end{array}$ \\
\hline $\begin{array}{l}\text { 4. Define the } \\
\text { biological } \\
\text { solution }\end{array}$ & $\begin{array}{l}\text { Identify the structures and surface mechanisms of the biological system } \\
\text { related to the recast function. }\end{array}$ \\
\hline $\begin{array}{l}\text { 5. Principle } \\
\text { extraction }\end{array}$ & $\begin{array}{l}\text { Extraction of the important principles of the solution in the form of a } \\
\text { neutral solution, requiring a description that removes, as much as } \\
\text { possible, the various structural and environmental constraints. }\end{array}$ \\
\hline $\begin{array}{l}\text { 6. Principle } \\
\text { application }\end{array}$ & $\begin{array}{l}\text { Translation of the bio-inspired solution principle extracted into a new } \\
\text { area, involving an interpretation of a domain space (e.g., biology) to } \\
\text { another (e.g., mechanics) by introducing new constraints. }\end{array}$ \\
\hline
\end{tabular}

Table 4. Bio-inspired design method (Helms et al., 2009). 


\begin{tabular}{|c|c|c|}
\hline Phase & $\begin{array}{c}\text { Description } \\
\begin{array}{c}\text { 1. Biological } \\
\text { identifion } \\
\text { 2. Define the } \\
\text { biological } \\
\text { solution }\end{array}\end{array}$ & $\begin{array}{c}\text { From the observation of natural phenomena on a macro scale and / or } \\
\text { a micro level, a potential solution to apply is sought to transfer to a } \\
\text { human problem. }\end{array}$ \\
\hline $\begin{array}{c}\text { 3. Principle } \\
\text { extraction } \\
\text { are identified in order to outline the biological solution in functional } \\
\text { notation. }\end{array}$ & $\begin{array}{c}\text { From the analysis of the biological solution in schematic notation, the } \\
\text { fundamental principle of the solution is extracted. }\end{array}$ \\
\hline $\begin{array}{c}\text { 4. Reframe the } \\
\text { solution }\end{array}$ & $\begin{array}{c}\text { In this case, reframing forces designers to think in terms of how } \\
\text { humans might view the usefulness of the biological function being } \\
\text { achieved. }\end{array}$ \\
\hline $\begin{array}{c}\text { 5. Problem } \\
\text { search }\end{array}$ & $\begin{array}{c}\text { Whereas search in the biological domain includes search through some } \\
\text { finite space of documented biological solutions, the search may include } \\
\text { defining new problems (this is much different than the solution search } \\
\text { step in the problem-driven processes). }\end{array}$ \\
\hline $\begin{array}{c}\text { 6. Problem } \\
\text { definition }\end{array}$ & $\begin{array}{c}\text { By analogy with the definition of the solution in schematic notation, } \\
\text { the problem is outlined similarly. The aim is thus to establish a parallel } \\
\text { between the systems and components of the biological solution and the } \\
\text { problem. }\end{array}$ \\
\hline $\begin{array}{c}\text { 7. Principle } \\
\text { application }\end{array}$ & $\begin{array}{c}\text { Once the solution principle is established, it is transformed into a } \\
\text { working principle of the technological concept that is needed. This } \\
\text { activity will culminate in the embodiment of a bio-inspired solution of } \\
\text { a technological product or system. }\end{array}$ \\
\hline
\end{tabular}

Table 5. Bio-solution in search of a problem method (adapted from Helms et al., 2009).

For the method presented in Table 4, the process of problem definition and searching for biological solutions is supported by elucidative techniques, suggestions and practical examples. The method presented in Table 5 supports an iterative formulation of the bioinspired design principle.

The application of bionic principles in a design project can be accomplished by following any of two opposing directions: finding a solution to a problem in nature, or looking for a problem for which a solution has been found in nature. The former approach starts with the identification of a problem (human applications, such as developing or improving products or services) or the need of a project, followed by looking for inspiration from nature or an analogy to foster a solution to the problem (a bionic solution proposal). This approach is well suited to designers seeking inspiration for the development of a particular product. The other approach is based on the observation of nature and its structures in order to collect useful information (bionic inspiration based solution) for human applications (design problems to be sought).

\section{Generally applicable goals for bio-inspired design}

This section presents an analysis of the likelihood of satisfaction of selected goals with the use of the five methods for bio-inspired design, retrieved from literature and presented in the previous section. Five general goals are proposed that are deemed to encompass many of the requirements pertaining to design projects for which inspiration from nature is 
sought. The goals were selected based on their perceived level of importance and their perceived ubiquitous relevance across design projects, albeit translated into a number of requirements, specific to the problems at hand. Communication effectiveness, form optimization, multiple requirements satisfaction, organization effectiveness and paradigm innovation for improved functional performance are the goals considered.

Effectiveness of communication depends on the sharing of a language that may be based on a code, gestures, or on signal that is appropriate to the activity and context. For effective communication to accrue it is necessary that the message is clearly delivered and received in a timely fashion, without noise, and that it is relevant to the situation or event that is ongoing.

Optimizing the shape of an object or structure can result directly from the balanced satisfaction (with concessions on both sides - trade-offs) of several key requirements, such as the reduction of material and, or, size, or the satisfaction of greater stability, or reduced drag, depending on the targeted objectives. It is not always possible to achieve an optimal configuration, with maximization of all properties due to inherent conflicts that they sometimes impart (e.g. contradiction between low weight and high strength or high volume or stability). Thus, optimization requires that the configuration reached is the one that best addresses the contradictions and conflicts between the desired properties.

Nature is rife with effective solutions in order to enable, in a limited space, a system to perform various tasks or fulfil several functions. Compliance with multiple requirements reflects the achievement of several key points that are inherent to the problem at hand, aiming for viability and profitability of a small number of structures and elements that are to be used in performing more than one function. This simultaneous satisfaction opens the way for consideration of new objectives to add value and profitability to the designed product or system. Compliance with various targets, carried out by a limited set of features, structures or entities implies streamlining for functional efficiency, which will result in resource savings.

The effectiveness of organization depends on the coordination of multiple structures (which also includes communication) for the performance of activities with the need of differentiation. The coordination of multiple entities in joint activity may lead to more effective results than the performance of the activity separately by each entity, such as that "the whole is greater than the sum of its parts". An example of excellent coordination and effectiveness of the resulting organization can be inferred from observation of the natural system comprised of a pack of wolves. The group can hunt animals larger than the wolf, while a lone wolf may only hunt smaller animals or of a scale similar to his. The organization of the roles of each element within the pack is a pre-condition for achieving this result.

Finally, the fifth goal considered consists in achieving change in the conventional paradigm used to implement a feature, replacing it with an innovative paradigm. The latter may be proposed based on the observation of structures, behaviours and, or, processes of nature that enable improved performance of the function or feature. The features can be characterized by transformation of physical state, state association or state hierarchy, to name a few. This goal is deemed to represent one of the most commonly sought goals by designers inclined to use a bionic approach.

\subsection{Likelihood of achieving the goals selected by using bio-inspired methods}

Considering the five goals presented, the five methods under focus were analysed in terms of their perceived support offered to designers making use of them towards the satisfaction 
of each goal. In what concerns the effectiveness of organization, a method oriented from the solution to the problem (Aalborg) is considered applicable to support the satisfaction of this goal, demonstrating that there are a few gaps remaining in order to lead to the full satisfaction of this goal. None of the problem-oriented methods analyzed is considered fully adequate to achieve this goal.

With regard to satisfying multiple requirements, methods oriented from the solution to the problem show, from the analysis, gaps in support to achieve this goal. The methods providing guidance in implementing bionic projects in the contrary direction of analysis, are very heterogeneous. While the method of bio-mimicry offers no support for the pursuit of this goal, in the opposite extreme, with considerable support, is the method of bio-inspired design.

When considering the goal of form optimization, one is faced with a relatively homogeneous landscape, with the methods only offering partial support to attain this goal. The exception of the method of spiral design is highlighted, as it is considered significantly applicable in order to achieve this purpose (this method provides guidance in following the direction from problem to solution).

In what concerns the innovation of paradigm for improved functional performance, all analyzed methods provide satisfactory guidelines which can support the achievement of this purpose. This demonstrates that the primary approach that has been recommended for bionic design centres on the functionality. Moreover, except for individual cases, the remaining goals have been given a minor importance. Although the Aalborg and biomimicry method ratings were similar (except for organizational effectiveness), the steps of the latter are more detailed than the ones of the former, and there is a descriptive complementarity between both. The need to integrate validation activities in the bioinspired design processes is emphasized, as only a few of the methods (the spiral design and Aalborg design methods) entail some evaluation and iteration. The development and testing of improved methods, providing broad support to pursuing a large scope of design goals, with support for validation of the quality of results attained, is hence necessary. The results of the overall analysis are presented in Table 6.

The bio-mimicry design method is only deemed "applicable with shortcomings" with regard to attaining the goals of optimizing form and improving effectiveness of organization. For the first goal, the assessment derives from the absence of iteration in order to pursue optimization (observing the morphological structure is what is suggested in the method that may provide limited support to pursuing this goal). For the second goal, the assessment takes into account that the method supports no direct account of organizational aspects, but only does that indirectly through structural analysis. The evaluation also results in suggesting the applicability of the method to support the pursuance of the goal of paradigm innovation for increased functional performance, and on the other hand, enables suggesting its non-applicability if the goal is to achieve satisfaction of multiple requirements and communication effectiveness.

The spiral design method was granted the rating of "Applicable with shortcomings" with respect to the goal of satisfying multiple requirements. In this method, satisfaction of multiple requirements may take place according to their explanation in the initial specification, if natural models demonstrating the reunion of the functions and, or, qualities sought are analysed. However, the method does not explicitly consider a way to guide the quest to satisfy multiple requirements. The goal of organizational effectiveness receives the same evaluation, as the aspect of organization is not considered directly in this method, but 
it is only implicit in the consideration of the analysis of ecosystems and natural social conditions. For the other goals at hand, this method proves to be applicable to support their satisfaction if the target is form optimization (especially given the nature of this iterative method, which favours systematic optimization) or innovation paradigm with regard to performance features. No support is perceived to attain the goal of communication effectiveness.

\begin{tabular}{|c|c|c|c|c|c|}
\hline \multirow[b]{2}{*}{$\begin{array}{c}\text { Bio-inspired } \\
\text { design } \\
\text { methods }\end{array}$} & \multicolumn{5}{|c|}{ Goals sought } \\
\hline & $\begin{array}{l}\text { Communication } \\
\text { effectiveness }\end{array}$ & $\begin{array}{c}\text { Form } \\
\text { optimization }\end{array}$ & $\begin{array}{l}\text { Multiple } \\
\text { requirements } \\
\text { satisfaction }\end{array}$ & $\begin{array}{l}\text { Organization } \\
\text { effectiveness }\end{array}$ & $\begin{array}{c}\text { Paradigm } \\
\text { innovation } \\
\text { for } \\
\text { improved } \\
\text { functional } \\
\text { performance }\end{array}$ \\
\hline $\begin{array}{c}\text { Bio-mimicry } \\
\text { (Junior et } \\
\text { al., 2002) }\end{array}$ & Not Applicable & $\begin{array}{l}\text { Applicable } \\
\text { with } \\
\text { shortcomings }\end{array}$ & Not applicable & $\begin{array}{l}\text { Applicable } \\
\text { with } \\
\text { shortcomings }\end{array}$ & Applicable \\
\hline $\begin{array}{c}\begin{array}{c}\text { Spiral } \\
\text { design } \\
\text { (Biomimicry } \\
\text { Inst., 2007) }\end{array} \\
\end{array}$ & Not Applicable & Applicable & $\begin{array}{l}\text { Applicable } \\
\text { with } \\
\text { shortcomings }\end{array}$ & $\begin{array}{l}\text { Applicable } \\
\text { with } \\
\text { shortcomings }\end{array}$ & Applicable \\
\hline $\begin{array}{c}\text { Bio-inspired } \\
\text { design } \\
\text { (Helms et } \\
\text { al., 2009) } \\
\end{array}$ & Not Applicable & $\begin{array}{l}\text { Applicable } \\
\text { with } \\
\text { shortcomings }\end{array}$ & Applicable & Not applicable & Applicable \\
\hline $\begin{array}{c}\text { Aalborg } \\
\text { (Colombo, } \\
2007) \\
\end{array}$ & Not Applicable & $\begin{array}{c}\text { Applicable } \\
\text { with } \\
\text { shortcomings }\end{array}$ & $\begin{array}{l}\text { Applicable } \\
\text { with } \\
\text { shortcomings }\end{array}$ & Applicable & Applicable \\
\hline $\begin{array}{c}\text { Bio-solution } \\
\text { seeks } \\
\text { problem } \\
\text { (Helms et } \\
\text { al., 2009) } \\
\end{array}$ & Not Applicable & $\begin{array}{c}\text { Applicable } \\
\text { with } \\
\text { shortcomings }\end{array}$ & $\begin{array}{l}\text { Applicable } \\
\text { with } \\
\text { shortcomings }\end{array}$ & Applicable & $\begin{array}{c}\text { Not } \\
\text { applicable }\end{array}$ \\
\hline
\end{tabular}

Table 6. Analysis of perceived support provided by the five bio-inspired design methods selected in attaining five fundamental design goals.

The bio-inspired design method shows gaps in the support offered to designers if the goal is to achieve optimal form, since the focus in this method is set on function. In some design processes supported by the procedures inherent to this method, the search for a biologically inspired solution to perform a given function could lead to considerations of form. However, the method does not provide procedures for optimization and does not explicitly consider form, or shape. The method is also deemed applicable in a satisfactory manner to problems where the targeted goal is either paradigm innovation for improved functional performance, or to satisfy multiple requirements, or a combination of both. However, it is not applicable to support the pursuance of the goals of effectiveness of either communication or organization. 
In the Aalborg method, which provides guidance in the direction from the solution to the problem, the degree of applicability to the goals of form optimization and satisfaction of multiple conditions, was assigned as "Applicable with shortcomings". For the first goal, despite the focus on form, there is no effort to optimize. Secondly, because shape, structure and functional principles are considered in this method the, implementation of multiple principles of form and structure may result from the analysis but is not explicitly considered. For the goals of innovation of paradigm for improved performance of functions and for effectiveness of organization, this method is deemed applicable.

For the bio-solution in search of a problem method, which is directed from the solution to the problem, as this method focuses on extracting and implementing the solution principle form nature, both the aspects of optimizing the shape and satisfying multiple requirements, are bound to be sidelined at the expense of the functional principle. The evaluation of this method and the previous one only differ significantly on the applicability to provide support to the pursuance of the goal of organizational effectiveness, because in this method there is no focus on the organizational structure of the biological system centred upon. The method is deemed applicable to support attaining the goal of paradigm innovation for increased functional performance.

\section{Validation of goal satisfaction in the bio-inspired design process}

The analysis presented in the previous section identified goals where the methods considered were deemed to either offer no support, or only offer reduced support, towards their pursuance and satisfaction. Moreover, only two of the methods (the spiral design method and the Aalborg method) entail some evaluation procedures, albeit limited in scope. This leads to suggest the integration of validation activities in bionic design processes, in order to ascertain whether the desired goals might be met by the use of the concepts generated with the support of bionic design methods. The current section presents a proposed validation approach, summarily depicted on Table 7, based on considering specific validation procedures matching each of the five goals focused in the previous section.

\subsection{Bio-inspired design case requirements}

Five methods that are intended to support the generation of bio-inspired design concepts, retrieved from literature, were analysed in this chapter. Three of these methods shared a common direction of analysis, which departs from a given problem and seeks the proposal of solutions by gathering insight and inspiration form natural systems. This approach begins with the identification of a problem or the needs of a project, which is followed by looking for inspiration from nature or seeking an analogy with a natural solution to foster the emergence of a solution to the problem (a bionic solution proposal).

A bionic design project was carried out, following an approach combining three of the methods reviewed (Junior et al. 2002, Biomimicry Inst. 2007, Helms et al. 2009). The problem considered was the storage and the physical display to enable browsing of personal music collections, focusing on CDs and DVDs. The conduction of the design process led to seek inspiration form nature, having selected the spider web as a natural example that was the basis for the analogy of working principle established. The requirements established for the project and their corresponding goals are listed in Table 8. Moreover, environmental 


\begin{tabular}{|c|c|}
\hline Goal & Validation procedures to evaluate goal accomplishment \\
\hline $\begin{array}{l}\text { Communication } \\
\text { effectiveness }\end{array}$ & $\begin{array}{l}\text { Validation is made according to the level of communication involved. } \\
\text { Passive communication (triggered by observation) - the } \\
\text { effectiveness may be evaluated by assessing the degree of the } \\
\text { overlap between the meaning intended to be incorporated into the } \\
\text { product or system by the designer and the readings of signification } \\
\text { made by users or observers (empirical verification). } \\
\text { Active communication (synchronous process between a sender and } \\
\text { a receiver) - effectiveness evaluated from the assessment of the } \\
\text { overlap between the messages from the sender and what is } \\
\text { perceived by the receiver, which should conform to what is desired } \\
\text { by the sender (empirical verification). }\end{array}$ \\
\hline $\begin{array}{c}\text { Form } \\
\text { optimization }\end{array}$ & $\begin{array}{l}\text { Validation based on a comparative approach with regard to a } \\
\text { conventional product with functionality that is similar to the one } \\
\text { intended for the bionic concept. Examples: } \\
\text { Reducing material and weight - analysis from solid modeling. } \\
\text { Stability - static analysis of mass centre (force vector modeling). } \\
\text { Resistance for maximum capacity - finite element method and } \\
\text { prototype testing. } \\
\text { Object storage - capacity, maximum capacity; quantification. }\end{array}$ \\
\hline $\begin{array}{l}\text { Multiple } \\
\text { requirements } \\
\text { satisfaction }\end{array}$ & $\begin{array}{l}\text { Validation based on objectively verifying, as much as possible, the } \\
\text { level that has been reached for each property implicit in every } \\
\text { requirement. This is followed by checking if the resolution of conflicts } \\
\text { between non-compatible properties was made with compromises } \\
\text { established on every side of the requirements concerned. }\end{array}$ \\
\hline $\begin{array}{l}\text { Organization } \\
\text { effectiveness }\end{array}$ & $\begin{array}{l}\text { Validation based on the comparison between two or more systems } \\
\text { performing the same function (including the proposed system), but } \\
\text { with different methods of organization. Collect measures of the levels } \\
\text { of operation effectiveness from the (real or simulated) systems } \\
\text { (including the proposed system), such as execution time, energy } \\
\text { expended, material resources expended, or resources generated. }\end{array}$ \\
\hline $\begin{array}{l}\text { Paradigm } \\
\text { innovation for } \\
\text { improved } \\
\text { functional } \\
\text { performance }\end{array}$ & $\begin{array}{l}\text { The evidence of paradigm change depends on the type of paradigm } \\
\text { involved. Consider these examples of two kinds of paradigm change: } \\
\text { Paradigm change at the organizational level - could involve } \\
\text { changing from a centralized model of decision making to a process } \\
\text { of cooperative decision making distributed and performed by } \\
\text { multiple system elements. } \\
\text { Paradigm change at the technical level - could involve } \\
\text { fundamental changes in working principle, shape archetype, drive } \\
\text { technology or kind of energy supplied. } \\
\text { The verification of the satisfaction of this goal may centre on a } \\
\text { conceptual-analytical argument distinguishing between the existing } \\
\text { and the new paradigm, possibly illustrated by descriptive imagery } \\
\text { and, or, technical schemes. }\end{array}$ \\
\hline
\end{tabular}

Table 7. Specific procedures suggested for consideration of the processes of validation of goals sought in bio-inspired design endeavours. 
concerns were expressed in terms of reduced environmental impact of materials, ease of maintenance and repair, as well as low weight of the product (and its package) for transportation. These requirements were dealt with in the design project, impinging on the selection of materials (selection of a bio-polymer and an organic elastomer) and on the design of the project (impinging on the goal of paradigm innovation for improved functional performance).

\begin{tabular}{|c|c|}
\hline Requirements & Goals sought* \\
\hline $\begin{array}{c}\text { 1. Nice and appealing shape, enabling the user to develop an } \\
\text { aesthetic interest in product }\end{array}$ & \multirow{2}{*}{$\begin{array}{l}\text { Communication } \\
\text { effectiveness }\end{array}$} \\
\hline $\begin{array}{l}\text { 2. Sending a message of an avant-garde character, creative and } \\
\text { youthful }\end{array}$ & \\
\hline $\begin{array}{l}\text { 3. Enhanced stability against a dynamic disturbance compared } \\
\text { with a conventional solution } \dagger\end{array}$ & \multirow{3}{*}{ Form optimization } \\
\hline 4. Increased lightness compared to conventional solution† & \\
\hline $\begin{array}{l}\text { 5. Proper positioning of the title of the CDs, DVDs and books for } \\
\text { enhanced readability }\end{array}$ & \\
\hline 6. Storage with versatility of CDs, DVDs or books & $\begin{array}{l}\text { Organization } \\
\text { effectiveness }\end{array}$ \\
\hline $\begin{array}{l}\text { 7. Enhanced gripping of objects compared with a conventional } \\
\text { solution }\end{array}$ & $\begin{array}{l}\text { Paradigm innovation } \\
\text { for improved } \\
\text { functional } \\
\text { performance }\end{array}$ \\
\hline
\end{tabular}

*- Satisfaction of multiple requirements is implicit in the consideration of the several requirements; $\dagger$ - Conflicting requirements, requiring a trade-off.

Table 8. Listing of requirements set for the bio-inspired design case presented and their corresponding goals that were sought.

The validation processes carried out within the exemplified design case used are summarily described, and an overview of the evidence used and the results obtained is provided in the following sub-sections, considering the goals depicted in Table 7. In what concerns the goal of satisfaction of multiple requirements, a conflict was detected between the requirement of enhanced stability and lightness. This conflict was solved by means of an approach akin to TRIZ (Altshuller 1994), with the contradiction solved by change of state, in the second iteration of the design. Bionic tower 2 hence encompasses a reservoir in the basis which may be filled with water or sand for added stability, while lightness is still guaranteed, for the sake of environmental concerns, especially focusing on the production and distribution phases of the product's life-cycle.

\subsection{Validation of communication effectiveness}

The perception by the user of pleasantness and appeal, enabling the development of an aesthetic interest in the product (first requirement in Table 8) was validated through a questionnaire where, among other things, each of the two bionic CD towers was visually compared, with a conventional tower (Figure 1). The validation of this requirement is necessarily subjective, because the key issue that arises relates to the taste and sensitivity of each individual questioned. Respondents, answering by email, accounted to 85, aged 
between 18 and 60, both male and female, and with diverse professional and knowledge specialities.
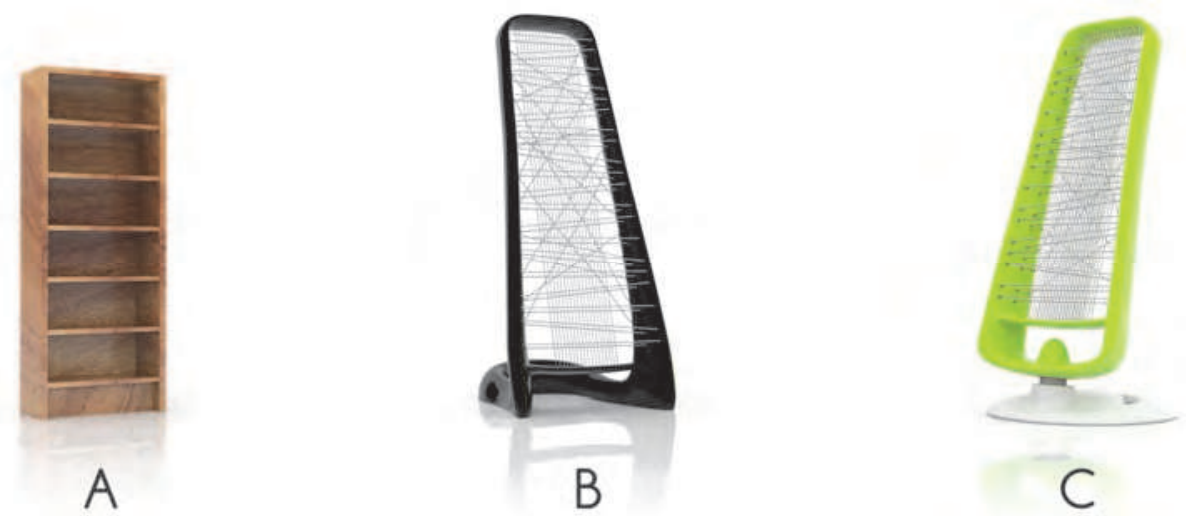

Fig. 1. Depiction of a conventional CD tower, and the two bio-inspired $C D$ tower racks designed: conventional tower(A), bionic tower 1 (B) and bionic tower 2 (C).

Each respondent indicated which of the CD racks was personally more aesthetically pleasing and appealing, from 3 paired comparisons presented. The paired comparisons approach applied to this case of three objects enables 8 possibilities of response, two of which are incongruent, since no ranking of preference can be established out of them. Three out of the 85 respondents reported incongruent paired comparisons. Thus, the analysis of results was carried out for 82 responses. The results were analysed on the basis of the procedure for calculating the Kendall coefficient of concordance (Siegel \& Castellan 1988). The average ranking obtained was bionic tower 1 (first place), bionic tower 2 (second place) and conventional tower (third place). This result is considered significant to represent the overall opinion of respondents to a confidence level of $99 \%$. These results support the validation of the first requirement depicted in Table 8 . Both the first and second bionic towers received the preference of respondents over the conventional tower, which supports the validation of the gains in terms of pleasantness and aesthetic appeal, for both versions of the bio-inspired design.

In what concerns the second requirement that contributes to the goal of effective communication, validation was sought by means of a technique of anthropomorphizing products through the attribution of personality dimensions. In a first phase, a translation of the requirement into a product personality profile (Jordan 2002) was proposed. In the second phase of the process, a sample of specialized public (eight undergraduate Industrial Design students) assessed the personality profile of the three objects shown in Figure 1. In such, whether or not the message intended by the designer was transmitted to the public could be verified.

The second requirement set in Table 8, was decomposed in a number of concepts to promote the matching process envisaged. This led to considering the attributes of modern, elegant, youthful, joyful, flexible and dynamic. Moreover the attributes consisting of lightweight and stable were also considered from the third and fourth requirements. The correspondence between product attributes intended by the designer to be perceived by the public and 
product personality dimensions (Jordan 2002) are shown in Table 9. The outcome of analysis on the respondents assessment of the personality profiles is also shown, based on evaluation of Kendall's coefficient of concordance (Siegel \& Castellan 1988).

For every personality pair, analysis was performed as exemplified for the pair energetic non energetic energy, the average ranking of the panel of respondents (with a significance of $99 \%$, given by the assessment of Kendall 's coefficient) resulted in the following rank order: 1st C, 2nd B, 3rd A. As a conclusion to this result, it is understandable that tower C (bionic tower 2) is considered more energetic than the tower $B$ (bionic tower 1 ), and that tower $C$ (conventional tower) is considered less energetic than tower $\mathrm{B}$. This means that tower $\mathrm{C}$ is deemed the least energetic of the three towers and that $C$ is the tower that emerges as the most dynamic and the less dynamic, thus validating this communication requirement.

\begin{tabular}{|c|c|c|c|c|}
\hline $\begin{array}{l}\text { Designer's } \\
\text { message }\end{array}$ & $\begin{array}{l}\text { Personality } \\
\text { profile }\end{array}$ & $\begin{array}{c}\text { Average } \\
\text { ranking } \\
1^{\text {st- }} 2^{\text {nd }}-3^{\text {rd }}\end{array}$ & $\begin{array}{l}\text { Significance } \\
\text { level of } \\
\text { Kendall's } \\
\text { coefficient of } \\
\text { concordance }\end{array}$ & Conclusion \\
\hline Modern & Bright - Dim & $B-A-C$ & Not significant & $\begin{array}{c}\text { Sample did not reveal } \\
\text { agreement }\end{array}$ \\
\hline Lightweight & $\begin{array}{l}\text { Simple - } \\
\text { Complex }\end{array}$ & $A-B-C$ & $99 \%$ & $\begin{array}{c}\text { Tower A is considered } \\
\text { most simple (lightweight) }\end{array}$ \\
\hline \multirow{2}{*}{ Elegant } & $\begin{array}{l}\text { Gentle - } \\
\text { Violent }\end{array}$ & $\mathrm{B}$ and $\mathrm{C}-\mathrm{A}$ & Not significant & $\begin{array}{l}\text { Sample did not reveal } \\
\text { agreement }\end{array}$ \\
\hline & $\begin{array}{l}\text { Moderate - } \\
\text { Excessive }\end{array}$ & $A-B-C$ & Not significant & $\begin{array}{c}\text { Sample did not reveal } \\
\text { agreement }\end{array}$ \\
\hline \multirow{3}{*}{ Youthful spirit } & \begin{tabular}{|c|} 
Liberal - \\
Authoritarian
\end{tabular} & $\mathrm{B}$ and $\mathrm{C}-\mathrm{A}$ & $99 \%$ & $\begin{array}{l}\text { Towers B and C are the } \\
\text { most liberal (youthful) }\end{array}$ \\
\hline & \begin{tabular}{c|} 
Rebel - \\
Conformist
\end{tabular} & $C-B-A$ & $99 \%$ & $\begin{array}{l}\text { Tower } C \text { is the most } \\
\text { rebellious (youthful) }\end{array}$ \\
\hline & $\begin{array}{l}\text { Optimistic - } \\
\text { Pessimistic }\end{array}$ & $B-C-A$ & Not significant & $\begin{array}{l}\text { Sample did not reveal } \\
\text { agreement }\end{array}$ \\
\hline \multirow[t]{2}{*}{ Joyful } & \begin{tabular}{|c|} 
Light-hearted \\
- Serious- \\
minded
\end{tabular} & $C-B-A$ & $99 \%$ & $\begin{array}{c}\text { Tower } C \text { is the most light- } \\
\text { hearted (joyful) }\end{array}$ \\
\hline & $\begin{array}{l}\text { Kind - } \\
\text { Unkind }\end{array}$ & $\mathrm{B}$ and $\mathrm{C}-\mathrm{A}$ & $95 \%$ & $\begin{array}{c}\text { Towers B and } C \text { are the } \\
\text { most kind (joyful) }\end{array}$ \\
\hline Flexible & $\begin{array}{l}\text { Flexible - } \\
\text { Inflexible }\end{array}$ & $C-B-A$ & Not significant & $\begin{array}{l}\text { Sample did not reveal } \\
\text { agreement }\end{array}$ \\
\hline Dynamic & $\begin{array}{l}\text { Energetic - } \\
\text { Unenergetic }\end{array}$ & $C-B-A$ & $99 \%$ & $\begin{array}{l}\text { Tower C is the most } \\
\text { energetic (dynamic) }\end{array}$ \\
\hline Stable & $\begin{array}{l}\text { Stable - } \\
\text { Unstable }\end{array}$ & $\mathrm{B}-\mathrm{A}-\mathrm{C}$ & Not significant & $\begin{array}{l}\text { Sample did not reveal } \\
\text { agreement }\end{array}$ \\
\hline
\end{tabular}

Table 9. Analysis of the results of the survey on the personality profile of the towers for CD and DVD storage and verification of messages perceived from observation of the objects by the pannel of undergraduate industrial design students. 
According to the findings obtained, the communication of a message of young spirit, dynamism and joyfulness were validated. Tower C (bionic tower 2 ) is the one which, according to the survey, more effectively conveys the desired messages, is considered the most dynamic, the most rebellious, most joyful and, together with tower B (bionic tower 1), most kind and most liberal. Regarding the transmission of the message of lightness, the personality profile related (simple - complex) did not translate so well the associated requirement. This might have led respondents to identify tower A (conventional) as the simplest, and therefore, according to the tenuous association, the lightest of the three. Interpretative meanings vary from person to person. The absence of actual experience of use of the towers on the part of respondents, who just exercised visual perception, may have also influenced and contributed to vagueness and lack of agreement among the respondents.

\subsection{Validation of form optimization}

The results concerning requirements contributing to the satisfaction of the goal of form optimization are shown in Table 10 (enhanced stability - according to force vector analysis), Table 11 (increased lightness - solid modelling analysis), Figure 2 (enhanced readability of CD titles - graphical depiction) and Figure 2 (scheme illustrating analytical stability modelling). For the first of the three requirements concerned by this goal, bionic tower 2 ranks in first place, while for the second requirement, bionic tower 1 is clearly the lightest, while for the last of the three requirements both bionic towers achieve a tie ahead of the conventional tower. The results support validation of the achievement of the goal sought of form optimization, albeit both bionic towers are deemed equivalent in this respect.

\begin{tabular}{|c|c|c|c|}
\hline $\begin{array}{c}\text { Maximum lateral } \\
\text { disturbance to } \\
\text { maintain stability }\end{array}$ & Conventional tower & Bionic tower 1 & Bionic tower 2 \\
\hline $\begin{array}{c}\text { At maximum } \\
\text { capacity }\end{array}$ & $49,96 \mathrm{~N}$ & $49,59 \mathrm{~N}$ & $74 \mathrm{~N}$ \\
\hline At medium capacity & $35,11 \mathrm{~N}$ & $29,57 \mathrm{~N}$ & $56,34 \mathrm{~N}$ \\
\hline
\end{tabular}

Table 10. Comparison of results for the maximum lateral disturbance tolerated without loss of stability in the three concepts.

\begin{tabular}{|l|l|l|l|}
\hline Total mass & Conventional tower & Bionic tower 1 & Bionic tower 2 \\
\hline Transport mode & $11,049 \mathrm{Kg}$ & $4,763 \mathrm{Kg}$ & $8,087 \mathrm{Kg}$ \\
\hline Use mode & $11,049 \mathrm{Kg}$ & $4,763 \mathrm{Kg}$ & $17,087 \mathrm{Kg}$ \\
\hline
\end{tabular}

Table 11. Comparison of mass data among the three objects. 


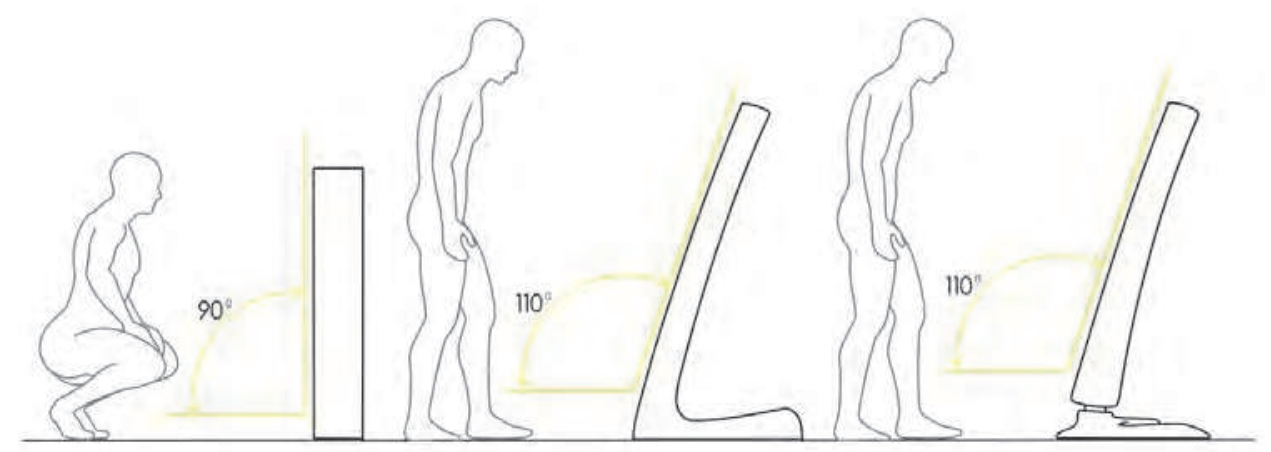

Fig. 2. Graphical depiction of readability of content titles for the three objects (from left to right: conventional tower, bionic tower 1 and bionic tower 2).
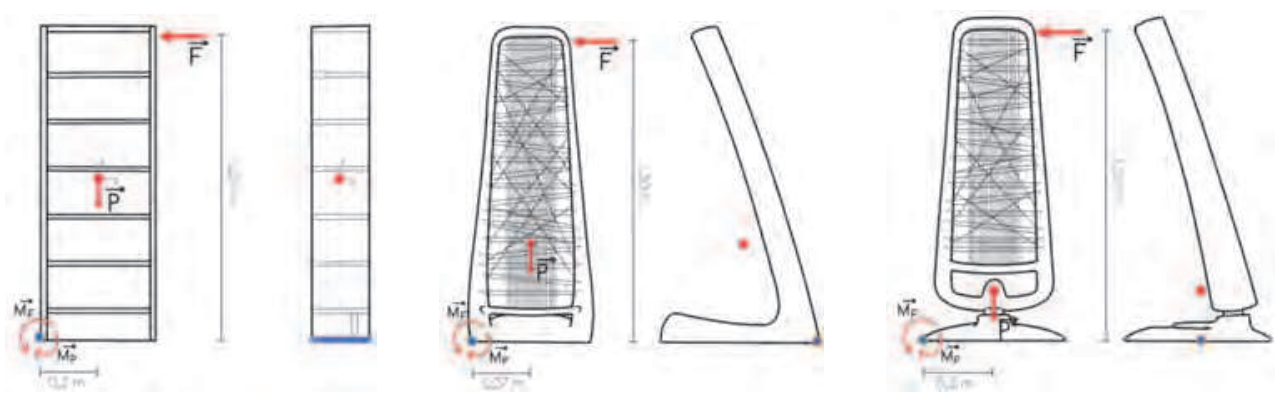

Fig. 3. Schematical depiction of analytical stability modelling for a lateral disturbance in the conventional CD rack, as well as in both the bionic towers designed.

\subsection{Validation of organization effectiveness}

To validate the goal of organization effectiveness, the proof of achievement of the requirement of storage with versatility of CDs, DVDs or books was sought by means of a graphical depiction (Figure 4) which is deemed self-explanatory with regard to this requirement's satisfaction.
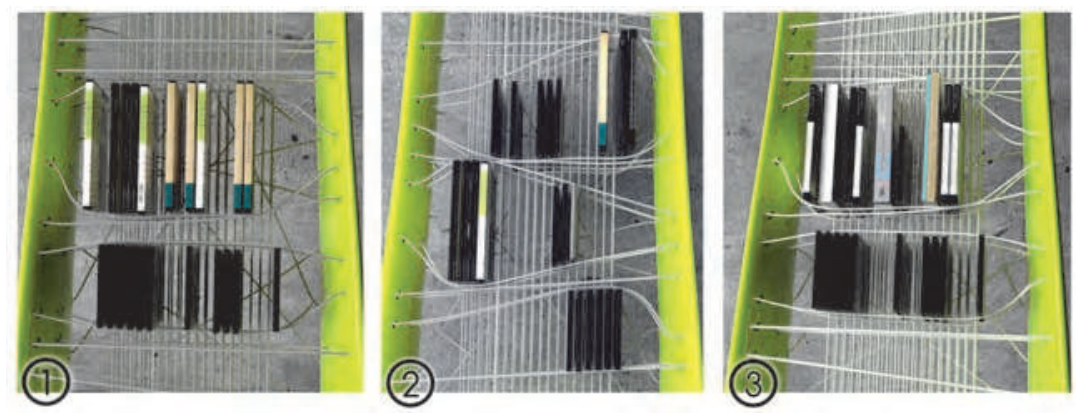

Fig. 4. Depiction of three possibilities of dynamic storage of objects in the bionic towers. 


\subsection{Validation of paradigm innovation for improved functional performance}

To validate the achievement of the goal of paradigm innovation for improved functional performance, verification of the achievement of the requirement of enhanced gripping of objects in the bionic towers was sought.
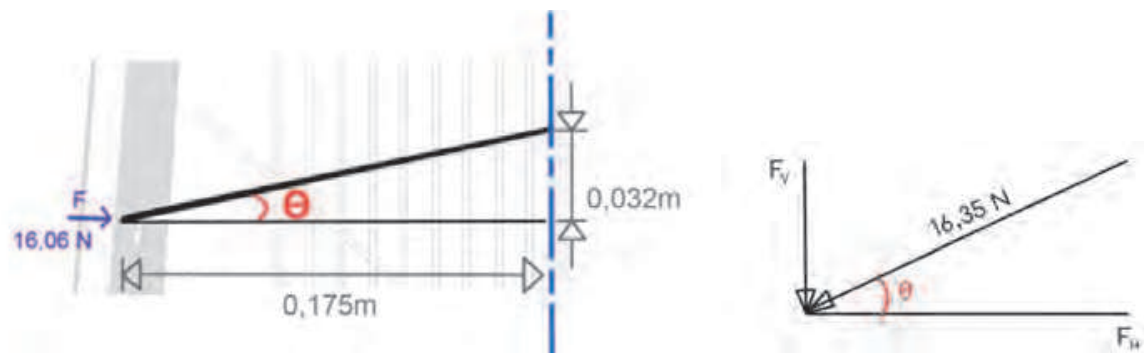

Fig. 5. Illustration of the changes in geometry of the web that generate object securing force.

Force and strength of material calculations were performed numerically and analytically, resulting in an estimation of approximately $0,5 \mathrm{~N}$ of vertical compression force per $\mathrm{CD}$ (based on analytical calculations developed from the physical comprehension of the phenomenon - Figure 5). Finite element modelling was pursued resulting in successful validation of the design for full capacity (Figure 6 - stress analysis under full capacity; Figure 7 - displacement under full load), yielding a safety factor of $166 \%$ and a maximum elastic (recoverable) displacement of $7.7 \mathrm{~cm}$.
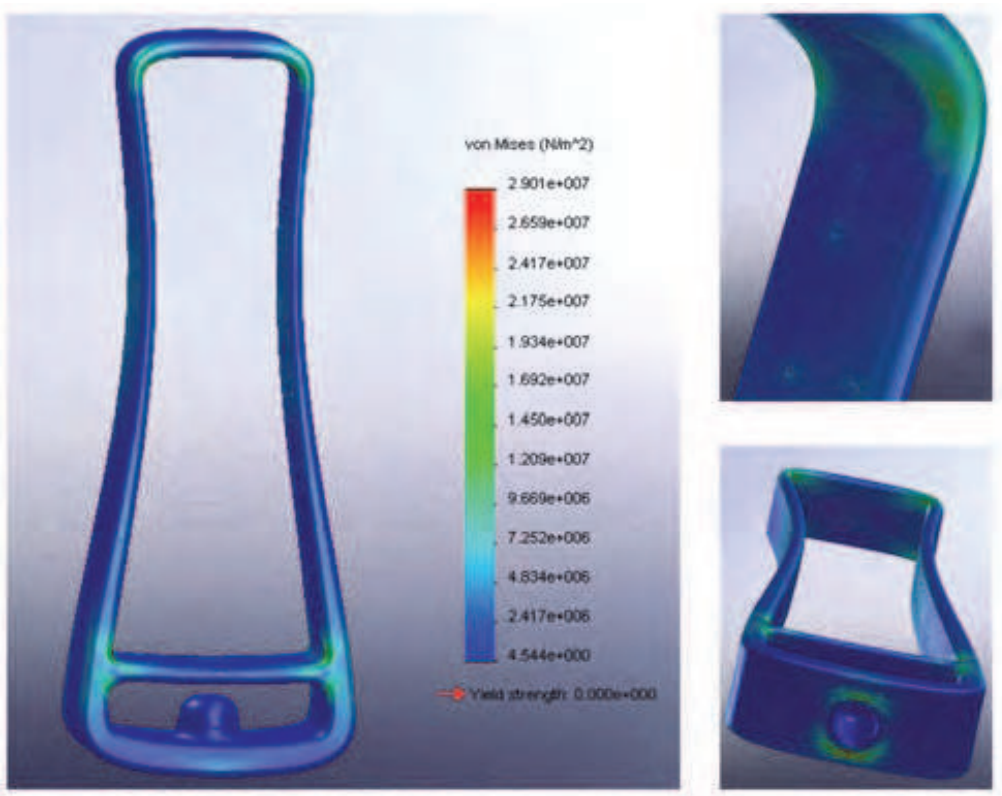

Fig. 6. Rendering of Von Mises stress analysis for bionic tower 2 frame under full load, obtained from educational 3D CAD software. 


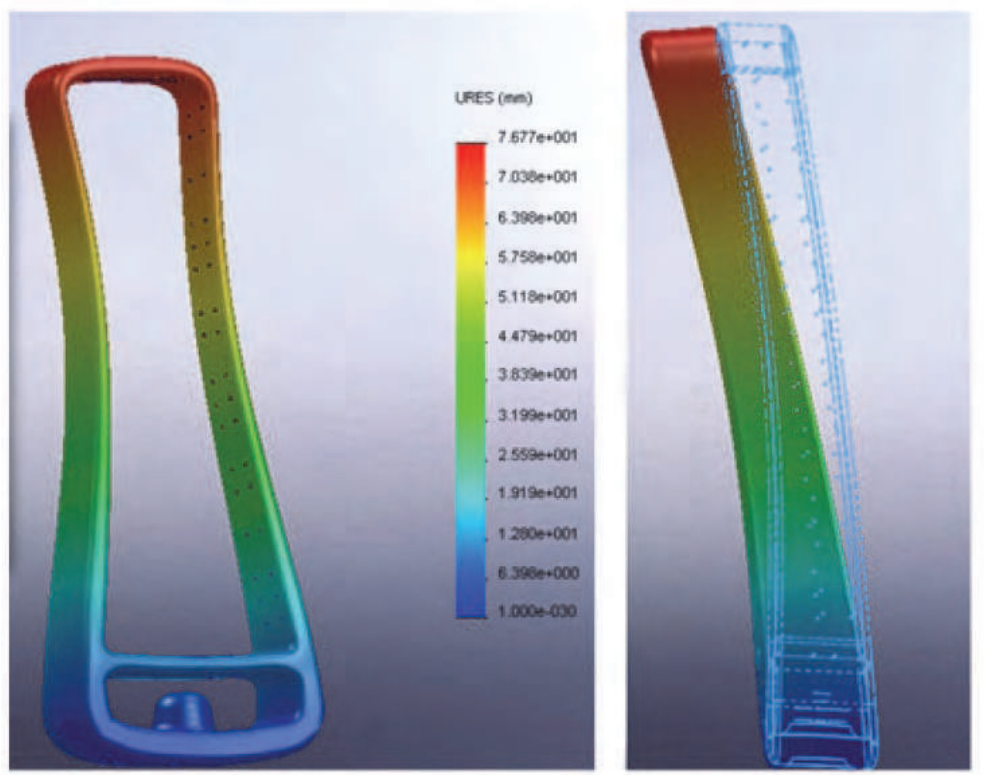

Fig. 7. Rendering of maximum elastic displacement for bionic tower 2 frame under full load, obtained from educational 3D CAD software.

\section{Conclusion}

From an industrial design perspective, the comparative analysis presented suggests that current methods to support bionic design, reported in literature, despite supporting specific goal satisfaction, are not effective across the whole spectrum of typical design goals. All the methods surveyed provide adequate support to the search for paradigm innovation, but form optimization, organization effectiveness and multiple requirement satisfaction are only adequately supported by some of the methods, albeit without any case of adequate support to all five goals found. Communication effectiveness is typically not supported in existing methods. The Aalborg method (Colombo, 2007) is deemed to adequately support attaining organization effectiveness, while the spiral design method (Biomimicry Institute, 2007) is deemed to adequately support attaining form optimization. Finally, the bio-inspired design method (Helms et al., 2009) is deemed applicable for problems seeking multiple requirements satisfaction, especially where trade-offs have to be established. Moreover, little support is given in the methods towards validation activities, concerning the satisfaction of the goals set for the design. The approaches to validation proposed in this chapter, combines engineering approaches with social science approaches to validation, in accordance with the nature of each of the goals focused. This validation process was demonstrated in a design case. Two variations of a novel bionic design for CD and DVD storage were designed using a combination of bio-inspired methods, and were then analysed in terms of satisfaction of requirements and validation of satisfaction of the goals sought, in comparison with a conventional solution for the same problem. This design case hence demonstrated the deployment of the validation process proposed in this chapter. 


\section{Acknowledgment}

The research presented in this chapter was developed as part of the first auhtor's Master of Science thesis in industrial design engineering and as part of his ongoing doctoral studies, both supervised by the second author. A selection of results from the projects reported in this chapter have previously appeared in the conference papers Coelho \& Versos (2010) and Versos \& Coelho (2010), as well as in Coelho \& Versos (2011) published by Inderscience and in Versos \& Coelho (2011) published by Common Ground.

\section{References}

Altshuller, H. (1994). The Art of Inventing (and Suddenly the Inventor Appeared), Translated by Lev Shulyak, Worcester, MA: Technical Innovation Center.

Benyus, J. (1997). Biomimicry - Inovation Inspired by Nature, New York: Harper Perennial

Biomimicry Institute. (2007). Biomimicry Institute - Board. URL: http://www.biomimicryinstitute.org/about-us/board.html (accessed December 29th, 2009).

Coelho, D.A. \& Versos, C.A.M. (2010). An Approach to Validation of Technological Industrial Design Concepts with a Bionic Character, Proceedings of the International Conference on Design and Product Development (ICDPD '10), Vouliagmeni, Athens, Greece, December 29-31, 2010.

Coelho, D.A. \& Versos, C.A.M. (2011). A comparative analysis of five bionic design methods, Int. Journal of Design Engineering, special issue Design in Nature, pages pending.

Colombo, B. (2007). Biomimetic design for new technological developments, in Salmi, E., Stebbing, P., Burden G., Anusionwu, L. (Eds) Cumulus Working Papers, Helsinki, Finland: University of Art and Design Helsinki, pp. 29-36.

Hales, C. (1991). Analysis of the Engineering Design Process in an Industrial Context, Eastleigh, UK: Gants Hill Publications.

Helms, M., Vattam, S.S., Goel, A. (2009). Biologically inspired design: process and products, Design Studies, Vol. 30, No. -, pp. 606-622.

Hubka, V. \& Eder, W.E. (1992). Enfürung in die Konstruktionswissenschaft - Übersicht, Modell, Anleitungen. Berlin: Springer Verlag.

Jordan, P. W. (2002). The Personalities of Products. In William S. Green and Patrick W. Jordan (Editors) Pleasure with Products: Beyond Usability, London: Taylor \& Francis, pp. 19-48.

Junior, W., Guanabara, A., Silva, E. \& Platcheck, E. (2002). Proposta de uma Metodologia para o Desenvolvimento de Produtos Baseados no Estudo da Biónica, Brasília: P\&D - Pesquisa e Design.

Kindersley, D. (1995). Máquinas Voadoras, Lisboa: Editorial Verbo.

Lage, A. \& Dias, S. (2003). Desígnio - Teoria do design, parte 2, Porto: Porto Editora.

Lloyd, E. (2008). The History of Bionics. URL:

http://www.brighthub.com/science/medical/articles/9070.aspx (accessed January 10th, 2010)

Lovegrove, R. (2004). Supernatural : the work of Ross Lovegrove, New York, NY : Phaidon.

Pahl, G. \& Beitz, W. (1996). Engineering Design - A systematic Approach, 2nd edition, London: Springer. 
Pernodet, P. \& Mehly, B. (2000). Luigi Colani - Biography, Paris: Dis Voir.

Roozenburg, N.F.M. \& Eekels, J. (1995). Product Design: Fundamentals and Methods, Chichester: John Wiley \& Sons.

Siegel, S. \& Castellan, N. J. (1988). Nonparametric Statistics for the Behavioural Sciences, New York: McGraw-Hill.

Ulrich, K.T. \& Eppinger, S.T. (2004). Product Design and Development, international edition, McGraw-Hill.

Versos, C.A.M. \& Coelho, D.A. (2010). Iterative Design of a Novel Bionic CD Storage Shelf Demonstrating an Approach to Validation of Bionic Industrial Design Engineering Concepts, Proceedings of the International Conference on Design and Product Development (ICDPD '10), Vouliagmeni, Athens, Greece, December 29-31, 2010.

Versos, C.A.M. \& Coelho, D.A. (2011). An Approach to Validation of Industrial Design Concepts Inspired by Nature, Design Principles and Practices: an International Journal, volume 5, pages pending. 


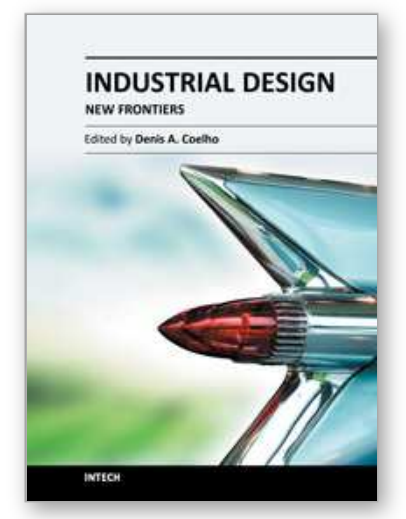

\author{
Industrial Design - New Frontiers \\ Edited by Prof. Denis Coelho
}

ISBN 978-953-307-622-5

Hard cover, 190 pages

Publisher InTech

Published online 09, November, 2011

Published in print edition November, 2011

A new breed of modern designers is on the way. These non-traditional industrial designers work across disciplines, understand human beings, as well as business and technology thus bridging the gap between customer needs and technological advancement of tomorrow. This book uncovers prospective designer techniques and methods of a new age of industrial design, whose practitioners strive to construct simple and yet complex products of the future. The novel frontiers of a new era of industrial design are exposed, in what concerns the design process, in illustrating the use of new technologies in design and in terms of the advancement of culturally inspired design. The diverse perspectives taken by the authors of this book ensure stimulating reading and will assist readers in leaping forward in their own practice of industrial design, and in preparing new research that is relevant and aligned with the current challenges of this fascinating field.

\title{
How to reference
}

In order to correctly reference this scholarly work, feel free to copy and paste the following:

Carlos A. M. Versos and Denis A. Coelho (2011). Biologically Inspired Design: Methods and Validation, Industrial Design - New Frontiers, Prof. Denis Coelho (Ed.), ISBN: 978-953-307-622-5, InTech, Available from: http://www.intechopen.com/books/industrial-design-new-frontiers/biologically-inspired-design-methods-andvalidation

\section{INTECH}

open science | open minds

\author{
InTech Europe \\ University Campus STeP Ri \\ Slavka Krautzeka 83/A \\ 51000 Rijeka, Croatia \\ Phone: +385 (51) 770447 \\ Fax: +385 (51) 686166 \\ www.intechopen.com
}

\author{
InTech China \\ Unit 405, Office Block, Hotel Equatorial Shanghai \\ No.65, Yan An Road (West), Shanghai, 200040, China \\ 中国上海市延安西路65号上海国际贵都大饭店办公楼 405 单元 \\ Phone: +86-21-62489820 \\ Fax: +86-21-62489821
}


(C) 2011 The Author(s). Licensee IntechOpen. This is an open access article distributed under the terms of the Creative Commons Attribution 3.0 License, which permits unrestricted use, distribution, and reproduction in any medium, provided the original work is properly cited. 